\title{
Exploring the Disclosure of Intellectual Capital in Ghana: Evidence from Listed Companies
}

\author{
Nicholas Asare*, Joseph Mensah Onumah and Samuel Nana Yaw Simpson
}

Department of Accounting, Methodist University College, Ghana

\begin{abstract}
Intellectual Capital (IC) has become a prominent feature of business transactions and discourse. The rising interests in IC and Intellectual Capital Disclosure (ICD) issues in both developed and developing countries have necessitated insightful studies. This study explores ICD in Ghana and seeks to contribute to fill the dearth in the literature on ICD from the perspective of developing countries. The study examines the ICD of 25 companies listed on the Ghana Stock Exchange (GSE) over a five-year period (2006-2010) through content analysis of their corporate annual reports. The study revealed that the ICD level in annual reports in Ghana is quite high and descriptively reported and though disclosure of $\mathrm{IC}$ is improving but at a relatively marginal rate. Therefore looking at the trend of ICDs by the companies, the study recommends the need for accounting regulatory bodies and oversight agencies (local and global) to develop specific standards or guidelines on identifying, measuring and reporting IC. This paper is one of the few studies to have investigated the disclosure of IC in corporate annual reports in Ghana.
\end{abstract}

Keywords: Intellectual capital; Disclosure; Corporate annual reports; Stakeholders

\section{Introduction}

Intellectual Capital (IC) is a term now in common usage across different fields of academic and managerial activity [1]. Roslender and Fincham [2] note that, while the term 'IC' is relatively new, the substance of the debate goes back to at least the 1960s and 1970s when many of the same topics were debated under the headings of 'Human Asset Accounting' or 'Human Resource Accounting'. The term IC was first used in the 1960s, but became pronounced in the 1990s and as result became an accounting/ management practitioner-created concept [36]. Since then, organizations have attached increased importance to the recognition, measurement and reporting of IC especially in corporate annual reports [7]. The increased focus on IC seems to be more related to the emergence of intangible assets as a key driver of value within knowledge based corporations, which is in turn a reflection of major macroeconomic economic shifts in most economies [8]. Edvinsson and Malone [9] argue that the worth of a company lies not in bricks and mortar, but in intangible kind of asset, that is IC, which is hidden behind the company's book values. Currently, companies are reporting on their IC in a qualitative or semi-quantitative manner in addition to the traditional and formally required financial reporting [10]. This can partly be traced to the increased demand by stakeholders for relevant information, prompted by the many frauds and scandals of the last decade which has demonstrated the need for there to be better rules and practices for financial information disclosure to improve trust in accounting [11].

To a large extent firms have much incentive to provide additional disclosure as previous literature identifies several reasons that pinpoint that enhanced disclosure has favorable capital market implications [12-14]. Disclosure can mitigate the adverse selection problem $[15,16]$ and improve market liquidity $[13]$ by providing value relevant information to otherwise uninformed investors [17]. Extensively ICDs forms a relative chunk of these disclosures that places the firm in proper perspective for investors and other stakeholders. Thus, a major premise is that firms disclose IC to improve transparency, legitimize status and enhance reputation [11]. Such a premise accords with contention by [8] that knowledge-based firms have strong reasons to improve transparency by disclosing IC information to stakeholders. This could be done through the corporate annual reports which have become noted for disclosing important/essential information about the financial and non-financial performance of companies.

There is a rising discussion of issues of IC in the context of the current knowledge/ information economy more largely within the accounting literature. However, a substantial portion of this prior research especially it's disclosures in annual reports have been undertaken in developed countries $[7,18,19]$. Thus, Kamath [18] calls for studies based on developing countries as part of the global attempt to develop disclosure guidelines on IC. In fact, there are no far-reaching regulations and guidelines that require companies to adhere to in disclosing IC [20]. Moreover, the International Financial Reporting Standards (IFRS) do not specifically and expressly require companies to report on IC, despite evidence that IC has become a key resource of value creation in today's knowledge economy [21].

This study therefore contributes to the literature by exploring the ICDs of companies in Ghana. The choice of Ghana stems from evidence that the country is one of the fastest growing countries; economically and democratically post World Bank and IMF sponsored reform programmers. Ghana was the first country in Sub-Saharan Africa to gain political independence from European colonial powers. Moreover, the country is considered by many scholars, the veritable site for researching into issues on Africa and developing countries [22]. The country maintains a mixed nature economy, with a modestly strong State and vibrant private sector [23].

This paper is organized as follows: the next section provides a

*Corresponding author: Nicholas Asare, Department of Accounting, Methodist University College, Ghana, Tel: 0302-312-980; E-mail: sirnickasare@yahoo.com

Received September 12, 2013; Accepted October 28, 2013; Published November 02, 2013

Citation: Asare N, Onumah JM, Simpson SNY (2013) Exploring the Disclosure of Intellectual Capital in Ghana: Evidence from Listed Companies. J Account Mark 2: 107. doi: 10.4172/2168-9601.1000107

Copyright: $\odot 2013$ Asare N, et al. This is an open-access article distributed under the terms of the Creative Commons Attribution License, which permits unrestricted use, distribution, and reproduction in any medium, provided the original author and source are credited. 
review of literature in the area. This is followed by details of the research method. Empirical results are presented in fourth section and findings discussed in the penultimate section. The final section presents some concluding remarks.

\section{Literature Review}

The business landscape has changed tremendously in the twenty-first century as we are entering the knowledge society, in which the basic economic resources are no longer capital, natural resources, or labor, but are, and will be, knowledge [24]. The notion of the "knowledge economy" has motivated much recent research (by academics, professional accounting bodies and various European Union (EU) and national government and international agencies), into why information relating to investments in intangible assets (e.g. IC), might be important in terms of better assessing and managing the sources of value generation and the sustainability and risks associated with corporate strategies.

In spite of these numerous research on IC, there are various definitions of IC in the literature, but Stewart's [25] definition appears to have received appreciable attention in the IC literature [26,27]. Stewart [25] defined IC as intellectual material - knowledge, information, intellectual property and experience - that can be put to use to create wealth. Other definitions give impetus to the fact that IC can be used to boost the wealth creation and firm value for sustain a competitive edge. Edvinsson and Malone [9] delineate IC as the possession of the knowledge, applied experience, organizational technology, customer relationships, and professional skills that give a company competitive edge in the market. Moreover, human beings, organizational structures and capabilities, customer base, organizational rapport with other stakeholders are emphasized.

Accounting regulation (for example, in the form of IAS 38: Intangible Assets) is conservative and restrictive in the extent to which it allows recognition and measurement of intangibles [28]. The friction is between ICD and accounting regulation as applied these days thereby signaling a need for a "revolution in accounting regulations" in order to ensure the fair presentation of the economic state of the firm [17]. In this regard the question that comes up is what Nielsen et al. [29] asked and endeavored to answer, i.e. how can we build an accounting system that enables the classification and presentation of IC indicators? They then went ahead and stated that, an accounting system for ICD would need to take into consideration the indicators of IC; which in turn must be classified according to common categories spanning the IC categories.

Over the years, a variety of approaches have been advanced to measure and report IC [30]. A system for classifying IC developed by Edvinsson et al. [31,32] proposed three components of IC, which they defined as human capital (HC) - individual competence, structural capital (SC) - internal structure and relational capital (RC) - external structure respectively.

The idea of $\mathrm{HC}$ and its significance for economic development can be found in the work of Smith (1976) [33]. HC is generally concerned with the contribution of human resources to organizational success. It generates innovation - whether of new products and services, or improving business processes [34]. Sonnier [35] described HC as the knowledge, skill, expertise/ know-how, problem solving capacity, education, training, judgment, experience, abilities, and loyalty of the employees of the firm. A further indebt explanation of the concept was by Abeysekera and Guthrie [36]. They referred to HC as "a combination of factors possessed by individuals and the collective workforce of a firm. It can encompass knowledge, skills and technical ability; personal traits such as intelligence, energy, attitude, reliability, commitment; ability to learn, including aptitude, imagination and creativity; desire to share information, participate in a team and focus on the goals of the organization". The HC is the brain behind the SC of every organization.

Moreover, SC encompasses the structure, processes, procedures, routines, systems and culture of the firm, including its databases, management tools, IT systems, strategies, structural design/mechanism, coordination mechanisms, policies, organizational learning capacity and networking systems [35]. Riahi-Belkaoui [34], also described it as "the knowledge that belongs to the organization as a whole in terms of technologies, inventions, data, publications, strategy and culture, structures and systems, organizational routines and procedures". It thus includes the complementary business assets that are often necessary to convert an innovative idea into a saleable product or service [6]. The $\mathrm{HC}$ and SC are both need if the organization is to have good RC assets to create value for various stakeholders.

On the other hand, $\mathrm{RC}$ is based on the idea that firms are considered not to be isolated systems but as systems that are, to a great extent, dependent on their relations with their environment [4]. Hormiga et al. [4] explained that $\mathrm{RC}$ refers to the value generated by relationships not only with customers or shareholders, but with all stakeholders, both internal and external. RC is thus the knowledge embedded in the relationships with any stakeholder that influences the organization's life [37]. This presupposes that in thriving as a firm, it is very important that the firm establishes and nurtures good and more progressive relationships with all its stakeholders.

These three IC categories can be perceived not to be disclosed proportionately in the corporate annual reports as there are no generally accepted stringent criteria for such disclosures especially in the context of Ghana. In that regard regulations/ standards in accounting regulate the reporting of information in corporate annual reports to the stakeholders. Accounting regulation is restrictive in the extent to which it allows recognition of intangibles. Nonetheless, prior evidence indicates that more disclosure can help solve problems of asymmetry in information between company insiders and investors $[14,16,38]$. Additional disclosure can lead to increased trading since it enhances firms ' visibility and investors are more likely to invest in firms they are familiar with [12,39]. Moreover, investors are likely to price protect themselves against potential losses from trading with wellinformed market participants [17]. As a result, a firm's cost of capital increases due to insufficient disclosure [14,38].

So firms have different motivations as to why they disclose IC. Generally, IC information disclosed in annual reports have the tendency to help various stakeholders especially investors to be familiar and satisfied with the affairs of firms so as to take informed decisions with regards to any dealings with the firms. The argument typically put forward by policy advisors appears to be that greater recognition, reporting and management of intangible assets e.g. IC could lead to significant improvements in corporate performance and that this information could provide both inside and outside stakeholders with valuable and relevant information concerning corporate risks and prospects [40]. Management of IC efficiently and effectively is the key to sustain competitive edge currently in specific industries.

Empirically, many of the ICD studies are based on evidence from 
the developed world and concentrated on organizations in the Nordic areas and English speaking countries, such as UK, USA, Canada and Australia [18,19]. Moreover, studies have relied on various media of disclosure, such as company websites, presentations to analysts and IPO prospectuses, but the annual report remains the most popular medium [41]. Furthermore, ICD in annual reports cuts across several sections of the reports. The sections include Chairman's Report (CR), Director(s) Report (DR), Auditor's Report, Corporate Governance Report (CG), Corporate Social Report (CSR), Financial Statements (FS) and Notes to the Financial Statements (N).

From the Australian context, Guthrie and Petty [42] report that IC is poorly understood, inadequately identified, inefficiently managed and not reported within a consistent framework when reported at all. European companies have pioneered the IC measurement and reporting field, and this trend is extending to Japan where guidelines for disclosure of IC have been issued. From the Scandinavia settings, many of the studies show sustained interest in accounting for the worth of employees, aptly identified via ICD [43]. They find that IC accounting developments in the UK is limited, thus has become the focus of interest within the sample of companies. Kansal and Singh [21] and Guthrie et al. [44] also find that levels of voluntary ICD by listed companies is low and in qualitative rather than quantitative form.

Focusing on intangible assets which IC is an example, report that firms with different background do not disclose intangible assets in the same way. These strengthen the view that ICD practices are not uniform across countries and firms. Abeysekera [45] argues that differences in ICD practices can be attributed to economic, social and political factors. More specifically Vergauwen and Alem [17] also pronounced that such difference can be explained by country-specific regulation and auditor conservatism. In spite of this, literature on the phenomenon in the context of developing countries and more specifically Sub-Saharan Africa may not be much to engineer evidence of ICD practices to international standard setters and stakeholders.

Recounting the few studies based evidence from Sub-Saharan Africa; Wagiciengo and Belal [7] reported that ICDs by South African companies have increased over the 5 years study period with certain firms and that out of the three components, $\mathrm{HC}$ is the most disclosed. Based on listed companies on the Nairobi Stock Exchange, Abeysekera [46] finds that those firms disclose more tactical SC and more strategic HC have larger boards. Tayib and Salman [47] also looked at Intellectual Capital Reporting (ICR) in Nigeria and found out that most of the IC indicators are not supported by accounting standards issued in Nigeria. More recently in Nigeria, Haji et al. [48], looked at ICD from a longitudinal perspective, the results show that the overall ICD of Nigerian banks increased moderately over the period and that human and internal capital disclosures dominated the banks' ICD.

\section{Research Method}

This study is primarily exploratory; there are little empirical studies on ICD in the context of developing countries and more specifically Ghana. The study draws on companies listed the Ghana Stock Exchange (GSE) as at the end of the year 2010. Out of the 36 listed firms as at that date, 25 were purposively sampled to include companies with at least five years annual reports. The reason for focusing the study on listed companies is that that they are more likely to disclose more information than unlisted companies and were assumed to appreciate issues of IC especially from the perspective that it could help them gain competitive advantage.
Annual report was the main source of data in light of evidence that it highly reliable and often used by managers of companies to signal what is important [49-51]. The annual report is an important document because it is the principal means for corporate communication of activities and intentions to stakeholders [52] it is produced regularly, the company has a substantial editorial input into it and it is widely distributed and read.

The 2006 - 2010 annual reports of the firms were gleaned and analyzed using content analysis method; widely used research methods in investigating the frequency and type of IC reporting. Content analysis involves codifying the text of writing (i.e. qualitative and quantitative information) into various pre-defined groups/classes or categories based on selected criteria in order to derive patterns in the presentation and reporting of information [51,44].

There are several units of content analysis of ICD; word, sentence and paragraph counts. Gray et al. [53], argue that words have the advantage of lending themselves to more exclusive analysis even though sentences are preferred in written communication if the task is to infer meaning. Using sentences for both coding and measurement is likely to provide complete, reliable and meaningful data for further analysis [54]. The argument for paragraph method is that, it is more appropriate than word count in drawing inferences from narrative statements as we commonly establish meaning with paragraphs rather than through the reporting of a word or sentence [51]. The literature does not provide an overwhelming justification for any of the three units of analysis [55]. However, the use of words and/or sentences seems to be preferred by most researchers. Drawing on the advantages that sentence count has over other units $[53,54]$ sentences are used as the recording unit just as previous studies. Wagiciengo and Belal [7] also add the need for an ICD framework.

On account of the exploratory nature of the current study and also based on a country specific study from Sub-Saharan Africa, Wagiciengo and Belal's [7] framework is adapted. Their framework was modified based on the Ghanaian regulatory environment, hence 30 indicators (i.e. 10 for each for the IC categories) assumed to be pertinent and applicable to all the firms were chosen (see table 1). The content analysis method was thus used to analyze the annual reports of the companies to determine the types of IC reported taken into consideration the various indicators/ attributes and categories of IC in the ICD framework. According to Guthrie et al. [51], the categories of classification must be clearly and operationally defined and objectively be clear that an item either belongs or does not belong to a particular category whilst a reliable coder is needed to be able to quantify the information.

An arithmetical coding format was used; an indicator reported (even repeated) was scored one (1) and a score of zero (0) if the indicator is not referred to [7]. The aggregate disclosure scores of IC indicators were aggregated to determine the ICD levels for a company and for each category of IC over the period. Also, in analyzing the ICD scores in the corporate annual reports, repeated ICD information was considered or recorded once.

\section{Discussions of Findings}

Drawing on the above framework, actual scores for a company and a category were out of a possible total disclosure score of 30 and 250 respectively. As can be seen from Table 2, the study shows that Ghana Commercial Bank Ltd and Standard Chartered Bank Ltd report 
Citation: Asare N, Onumah JM, Simpson SNY (2013) Exploring the Disclosure of Intellectual Capital in Ghana: Evidence from Listed Companies. J Account Mark 2: 107. doi: 10.4172/2168-9601.1000107

Page 4 of 7

\begin{tabular}{|c|c|c|c|c|c|}
\hline & Human Capital & & Structural Capital & & Relational Capital \\
\hline 1 & Career planning/ development & 1 & Corporate culture & 1 & Partnerships and Alliances \\
\hline 2 & Education & 2 & Information systems & 2 & Community Involvement \\
\hline 3 & Employee demographics & 3 & Intellectual property & 3 & Competitors \\
\hline 4 & Remuneration Incentives & 4 & Management philosophy & 4 & Customer\& Supplier \\
\hline 5 & Industrial relations & 5 & Management processes & 5 & Distribution channels \\
\hline 6 & Innovation, Initiative, motivation & 6 & Organizational learningcapacity & 6 & Favourable contracts \\
\hline 7 & Know-how and experience & 7 & Organizational structure & 7 & Financial relations \\
\hline 8 & Occupational health and Safety & 8 & Policies and procedures & 8 & Investors \\
\hline 9 & Teamwork capacity & 9 & Quality services/products & 9 & Licensing/franchising \\
\hline 10 & Training \&Work-related Competencies & 10 & R\&D & 10 & Organisation name/ brands \\
\hline
\end{tabular}

Table 1: The ICD Framework.

\begin{tabular}{|c|c|c|c|c|c|c|}
\hline Company & 2006 & 2007 & 2008 & 2009 & 2010 & Average \\
\hline & Score & Score & Score & Score & Score & Score \\
\hline Ghana Commercial Bank Ltd & 21 & 21 & 23 & 23 & 24 & 22.4 \\
\hline Standard Chartered Bank Ltd & 22 & 21 & 20 & 24 & 25 & 22.4 \\
\hline HFC Bank Ltd & 21 & 20 & 21 & 23 & 24 & 21.8 \\
\hline Enterprise Insurance Company Ltd & 21 & 20 & 20 & 22 & 24 & 21.4 \\
\hline SG-SSB Ltd & 20 & 20 & 21 & 22 & 23 & 21.2 \\
\hline CAL Bank Ltd & 21 & 20 & 20 & 22 & 22 & 21 \\
\hline Mechanical Lloyd Company Ltd & 19 & 19 & 21 & 21 & 22 & 20.4 \\
\hline PZ Cussons Ltd & 19 & 20 & 19 & 19 & 21 & 19.6 \\
\hline Pioneer Kitchenware Ltd & 19 & 18 & 21 & 18 & 22 & 19.6 \\
\hline Total Petroleum Ltd & 19 & 18 & 18 & 18 & 20 & 18.6 \\
\hline Aluworks Ltd & 16 & 16 & 17 & 19 & 22 & 18 \\
\hline Accra Brewery Company Ltd & 18 & 17 & 19 & 16 & 16 & 17.2 \\
\hline Guinness Ghana Breweries Ltd & 13 & 15 & 15 & 21 & 22 & 17.2 \\
\hline Benso Oil Palm Plantation Ltd & 16 & 16 & 16 & 17 & 19 & 16.8 \\
\hline Produce Buying Company Ltd & 14 & 15 & 17 & 17 & 19 & 16.4 \\
\hline Unilever (Ghana) Ltd & 14 & 15 & 17 & 18 & 17 & 16.2 \\
\hline Cocoa Processing Company Ltd & 16 & 15 & 16 & 18 & 14 & 15.8 \\
\hline Fan Milk Ltd & 11 & 16 & 16 & 18 & 18 & 15.8 \\
\hline Starwin Products Ltd & 18 & 15 & 15 & 15 & 15 & 15.6 \\
\hline Golden Web Ltd & 14 & 14 & 15 & 16 & 16 & 15 \\
\hline Camelot Ghana Ltd & 12 & 14 & 12 & 13 & 15 & 13.2 \\
\hline Sam Wood Ltd & 13 & 13 & 13 & 14 & 13 & 13.2 \\
\hline Clydestone Ltd & 13 & 12 & 12 & 14 & 15 & 13.2 \\
\hline CFAO Ltd & 8 & 10 & 14 & 11 & 13 & 11.2 \\
\hline African Champions Industries Ltd & 10 & 11 & 10 & 12 & 12 & 11 \\
\hline Average & 16.32 & 16.44 & 17.12 & 18.04 & 18.92 & 17.37 \\
\hline
\end{tabular}

Table 2: Rankings by Companies' ICD Scores.

more on IC in their annual reports hence have the highest average ICD score of 22.40 over the period. On the other hand, African Champions Industries Ltd had the lowest ICD score with an average of 11.00 compared to the overall average of 17.35 of the total ICD indicators over the period. The overall average ICD score was $57.89 \%$ of the IC indicators. The average disclosure score for all the firms increased from 16.32 in 2006 to 18.92 in 2010 (i.e. 15.93\% increase over the period); indicating that ICDs for the firms increased at marginal rates over the period. This illustrate the gradual way at which ICD in corporate annual reports is improving in such reports; and could indicates that the firms are not so enthused about increasing such disclosures at higher rates within the foreseeable future.

In the specific instance of Ghana Commercial Bank Ltd and Standard Chartered Bank Ltd, they are among the largest banks and/ or listed firms in the country in terms of their market share and market capitalization in the banking industry and GSE bourse respectively and as such do not seem to surprise the researchers that they disclose more
IC than any of the sampled companies. Moreover, firms in the banking, finance and insurance industry appear more conversant with IC issues as evidence from Table 2 indicates that all of them were ranked among the first ten. The first six firms are all from the banking, finance and insurance industry and they form the total number of companies from that sector included in this study. This could be attributed to their quest to achieve competitive advantage as a result of the competitive nature of that industry coupled with stringent regulatory regime of their industry.

Overall, the ICD level was relatively high as more than half of the IC indicators were disclosed by the listed firms on average over the period. This is somehow commendable and shows that Ghanaian listed firms have appreciable understanding of the practice of ICD.

With this observation the researchers went further to find out the IC category that was relatively disclosed than the others using the average ICD scores cautiously. It can be seen from Table 3 that SC (133 
in 2006 to 157 in 2010) and HC (141 in 2006 to 153 in 2010) increased sporadically over the period, but RC (135 in 2006 to 158 in 2010) increased continuously, hence the relatively dominant component (mean of 149.6). This reveals that RC disclosures in corporate annual reports are relatively higher than $\mathrm{HC}$ and SC disclosures among listed firms in Ghana. It could be inferred by the researchers that in the quest of listed firms to provide adequate disclosures with respect to IC they disclose more RC indicators as probably they treasure relationships built with stakeholders. Though this findings differ from Wagiciengo and Belal [7] findings; the dominance of HC, it is consistent with findings that RC disclosures are relatively higher than $\mathrm{HC}$ and $\mathrm{SC}$ disclosures $[21,56]$.

Also, from Table 4, RC indicators were relatively disclosed most, with an average $58.48 \%$ of companies disclosing on them over the period. Coincidentally RC is also quite the most disclosed in the annual reports and as such is not surprising that a greater number of companies are disclosing it in their annual reports than the others. This was followed closely by SC indicators i.e. with an average of $57.68 \%$ companies disclosing it over the period. The latter was not significantly different from the number of firms that disclosed the RC. A further perusal of the analysis using the 30 IC indicators used in this study indicated that, the most disclosed IC indicator was 'management processes'. This was on average disclosed by all the companies (i.e. 24.8 representing $99.2 \%$ ) for the period. This was followed closely by 'Information systems/ technology'; an average of 24.4 representing $97.6 \%$ companies. The least disclosed indicator was 'Industrial Relations'.

These findings suppose that issues of management or technical processes (series of actions) implemented/ to be implemented to achieve specific results in the firms are always disclosed in the corporate annual reports coupled with information on systems or networking stuffs. Labor union relations and activities i.e. 'Industrial Relations' disclosures are hardly disclosed by majority of the listed firms.

In terms of the three categories; for the HC category, issues of remuneration and incentives are the one disclosed by most of the companies (i.e. 23.60 representing $94.40 \%$ ); with SC, management processes was on average disclosed by all the companies (i.e. 24.8 representing $99.20 \%$ ) and as such is the most disclosed by the companies over the period; RC's most disclosed attribute was "financial relations (i.e. references to recognized associations with financial institutions)", 23.60 firms representing $94.40 \%$ of the sampled firms.

The analysis of ICD by its locations in the sections of the annual reports as shown in Table 5 basically revealed that the chairman's report contains the most of ICDs (approximately $28 \%$ of the total ICDs over the period). $24 \%$ and $23 \%$ of all ICDs over the period were disclosed in notes to the financial statements and director(s) report sections correspondingly. The sections with the least amount of disclosures were the financial statements and corporate social report (i.e. $2 \%$ of total ICDs). The results for the directors' report as against the chairman's report and notes to the financial statements can be partly explained that considerable portion of what should be in the directors report and financial statements is dictated by the companies code 1963 (i.e. in the context of Ghana) and accounting standards respectively. With regards to the accounting standards there are no clear cut standards enjoining firms to recognize IC in financial statements. Corporate governance issues have also hyped the chairman's report of the annual reports and could invariably be a factor as to what information is disclosed in that report.

Also, the disclosure of IC for all the sections of the annual reports increased irregularly over the period; pinpointing the gradual improvement with which ICDs in the various sections of corporate annual reports have been over the period. The low ICD in financial statements section certainly is clarified by the piece of evidence in this report that, most of the companies reported IC in qualitative form. According to Guthrie et al. [44], this ought to be expected, as there are no corporation laws or accounting standards that require the quantification of IC. The fact is that generally intangibles do not meet the stringent criteria of the monetary measurement concept as stipulated in the GAAP and are voluntarily disclosed in discursive form.

Consistent with Guthrie et al. [44], most of the ICDs were mostly in qualitative form (i.e. descriptive form); about $95 \%$ of total ICDs over the period (see Figure 1). This supports the general perception that ICDs in annual reports are mostly in words or descriptive form.

\section{Conclusion}

This study sought to examine the level of ICD of listed companies via content analysis of their corporate annual reports. A sample of 25 firms listed on the Ghana stock exchange was used in 0the study. The ICD level was relatively high and mostly in qualitative form. This obviously puts listed firms as being concerned with their ICD in the annual reports even though very little is being done to quantify those assets in monetary and numerical terms. The disclosures are fairly dominated by RC indicators and are mostly in the chairman's report section of the annual reports. Issues of management or technical processes (series of actions) implemented/ to be implemented to achieve specific results in the firms are always disclosed in the corporate annual reports coupled with information on systems or networking stuffs. Labour union relations and activities i.e. 'industrial relations' disclosures are hardly disclosed by majority of the listed firms. Besides, the banking \& finance and insurance industry as a knowledge intensive sector have comparatively high ICDs as the all the 6 companies from that sector were ranked the top six in the ICD score rankings. On the whole, conclusion can be made that, the disclosure of IC in Ghana is improving but at a relatively low rate. Various ICD approaches could be adopted or adapted to raise disclosures to a more desirable or more excellent quality. The standards and guidelines will speed up the improvements in the ICD in the annual reports.

Companies should voluntarily increase the content, in terms of quantity and quality, of ICDs in corporate annual reports and other equally important reports. In that regard management should ensure that they are consistent in their ICD practices by instituting mechanisms

\begin{tabular}{|l|c|c|c|c|c|}
\hline & $\mathbf{2 0 0 6}$ & $\mathbf{2 0 0 7}$ & $\mathbf{2 0 0 8}$ & $\mathbf{2 0 0 9}$ & $\mathbf{2 0 1 0}$ \\
\hline HC & 141 & 141 & 139 & 149 & 153 \\
\hline SC & 133 & 131 & 137 & 148 & 157 \\
\hline RC & 135 & 139 & 152 & 148 & 1.6 \\
\hline Average & 136.33 & 137 & 142.67 & 151.67 & 158 \\
\hline
\end{tabular}

Table 3: ICD Scores for IC Categories. 
Citation: Asare N, Onumah JM, Simpson SNY (2013) Exploring the Disclosure of Intellectual Capital in Ghana: Evidence from Listed Companies. J Account Mark 2: 107. doi: 10.4172/2168-9601.1000107

Page 6 of 7

\begin{tabular}{|c|c|c|}
\hline \multirow[b]{2}{*}{ Human Capital } & \multicolumn{2}{|c|}{ Average (2006-2010) } \\
\hline & No. of Companies & $\%$ \\
\hline Remuneration and Incentives & 23.6 & 94.4 \\
\hline Innovation, Initiative, motivation & 20.6 & 82.4 \\
\hline Know-how and experience & 20.2 & 80.8 \\
\hline Education & 16.8 & 67.2 \\
\hline Training \&Work-related competencies & 16.6 & 66.4 \\
\hline Teamwork capacity & 12 & 48 \\
\hline Employee demographics & 10.8 & 43.2 \\
\hline Career planning/development & 10.2 & 40.8 \\
\hline Occupational health and Safety & 9.8 & 39.2 \\
\hline Industrial relations & 2.2 & 8.8 \\
\hline Average & 14.28 & 57.12 \\
\hline \multicolumn{3}{|l|}{ Structural Capital } \\
\hline Management processes & 24.8 & 99.2 \\
\hline Information systems & 24.4 & 97.6 \\
\hline Policies and procedures & 24.2 & 96.8 \\
\hline Corporate culture & 22.8 & 91.2 \\
\hline Management philosophy & 15.2 & 60.8 \\
\hline Quality services/products & 11.2 & 44.8 \\
\hline$R \& D$ & 7.8 & 31.2 \\
\hline Intellectual property & 5 & 20 \\
\hline Organizational learning capacity & 3.2 & 12.8 \\
\hline Organisational structure & 3.2 & 12.8 \\
\hline Average & 14.18 & 56.72 \\
\hline \multicolumn{3}{|l|}{ Relational Capital } \\
\hline Financial relations & 21.6 & 86.4 \\
\hline Investors & 20.2 & 80.8 \\
\hline Partnerships and Alliances & 18.8 & 75.2 \\
\hline Customer \&Supplier & 17.8 & 71.2 \\
\hline Distribution channels & 18.2 & 72.8 \\
\hline Organisation name/ brands & 15.6 & 62.4 \\
\hline Community Involvement & 14.6 & 58.4 \\
\hline Competitors & 8.2 & 32.8 \\
\hline Licensing/franchising & 7 & 28 \\
\hline Favourable contracts & 4.6 & 18.4 \\
\hline Average & 14.66 & 58.64 \\
\hline
\end{tabular}

Table 4: Number of Companies by Reported Indicators.

\begin{tabular}{|l|l|l|l|l|l|l|l|l|}
\hline Year & DR & CR & CG & AR & FS & N & CSR & Total \\
\hline $\mathbf{2 0 1 0}$ & 184 & 231 & 98 & 80 & 16 & 190 & 16 & 815 \\
\hline $\mathbf{2 0 0 9}$ & 181 & 217 & 83 & 71 & 21 & 180 & 19 & 772 \\
\hline $\mathbf{2 0 0 8}$ & 175 & 202 & 81 & 70 & 16 & 182 & 12 & 738 \\
\hline $\mathbf{2 0 0 7}$ & 163 & 185 & 72 & 71 & 17 & 170 & 12 & 690 \\
\hline $\mathbf{2 0 0 6}$ & 169 & 197 & 88 & 71 & 14 & 173 & 12 & 724 \\
\hline Total & 872 & 1032 & 422 & 363 & 84 & 895 & 71 & 3739 \\
\hline Percent (\%) & 23.32 & 27.6 & 11.29 & 9.71 & 2.25 & 23.94 & 1.9 & 100 \\
\hline
\end{tabular}

Table 5: Location of ICDs in Corporate Annual Reports over the Period (20062010).

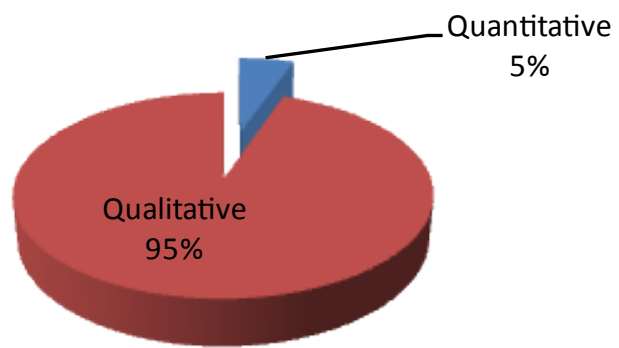

Figure 1: Proportion of Qualitative and Quantitative ICDs

to ensure the provision of relevant and reliable IC information. Stakeholders are encouraged to incorporate IC information in their decisions since it will help them to make good decisions with regards to their dealings with companies.

As there is no distinctive model/approach for ICD, various approaches have been adapted to measure and report IC in the specific context of the companies and industries; thus showing how disparaging the practice of ICD in annual reports is across the country. There should be harmonization of the practices across the world by accounting standards. Efforts by accounting regulatory bodies should be intensified in coming out with specific standards. Therefore looking at the trend of ICDs by the companies i.e. is improving but at a relatively low rate, the study recommends the need for accounting regulatory bodies and oversight agencies (local and global) to develop specific standards or guidelines on identifying, measuring and reporting IC in corporate annual reports. Managers of listed companies on the other hand should continue to improve their disclosures by disclosing relevant and reliable information on IC for stakeholder use. In the light of these recommendations future research work could be undertaken to improve the ICD practices in Ghana.

A similar study could also be undertaken in unlisted companies and state owned enterprises. This current study looked at the extent and level of disclosure of IC in corporate annual reports. Future research may well be made to ascertain the quality of the disclosed IC and the willingness of management to make such disclosures in spite of its being primarily voluntary. The study focused on five years corporate annual reports. Imminent research could extend the time period covered in order to observe the development of ICD over a longer period.

This study was limited to selected listed companies on the GSE. Content analysis as a methodology, itself is subject to its own inherent limitations. The result of the study therefore may not necessarily represent the general situation in all companies in Ghana.

\section{References}

1. Gowthorpe C (2009) Wider still and wider? A critical discussion of intellectual capital recognition, measurement and control in a boundary theoretical context. Crc Perspect Account 20: 823-834.

2. Roslender R, Fincham R (2001) Thinking critically about intellectual capital accounting. Account, Auditing and Accountability J 14: 383-399.

3. Atalay M, Anafarta N (2011) Enhancing Innovation Through Intellectual Capital: A Theoretical Overview. J Mod Account and Auditing 7: 202-210.

4. Hormiga E, Batista-Canino RM, Sánchez-Medina A (2010) The Role of Intellectual Capital in the Success of New Ventures. IntEntrepManag J

5. Schneider A, Samkin G (2008) Intellectual Capital Reporting by the New Zealand Local Government Sector. J Intellectual Capital 9: 456-486.

6. Sullivan PH (1999) Profiting from Intellectual Capital. J Knowl Manage 3: 132 142

7. Wagiciengo MM, Belal AR (2012) Intellectual Capital Disclosures by South African Companies: A Longitudinal Investigation. Advances in Accounting 28: 111-119.

8. McPhail K (2009) Where is the ethical knowledge in the knowledge economy? Power and potential in the emergence of ethical knowledge as a component of intellectual capital. Crc Perspect Account 20: 804-822.

9. Edvinsson L, Malone MS (1997) Intellectual capital: Realizing your company's true value by finding its hidden brainpower. Harper Business, New York.

10. Boekestein B (2009) Acquisitions Reveal the Hidden Intellectual Capital of Pharmaceutical Companies. J Intellectual Capital 10: 389-400.

11. Oliveira L, Rodrigues LL, Craig R (2006) Firm-Specific Determinants Of Intangibles Reporting: Evidence from the Portuguese Stock Market. J Hum Resource Costing \& Account 10: 11-33. 
Citation: Asare N, Onumah JM, Simpson SNY (2013) Exploring the Disclosure of Intellectual Capital in Ghana: Evidence from Listed Companies. J Account Mark 2: 107. doi: 10.4172/2168-9601.1000107

Page 7 of 7

12. Diamond DW, Verrecchia RE (1991) Disclosure, Liquidity, and the Cost of Capital. J Financ 46: 1325-1359.

13. Healy PM, Hutton AP, Palepu KG (1999) Stock Performance and Intermediation Changes Surrounding Sustained Increases in Disclosure. Contemp Account Res 16: 485- 520.

14. Leuz C, Verecchia RE (2000) The economic consequences of increased disclosure. J Account Res 38: 91-124.

15. Akerlof G (1970) The market for lemons: Quality uncertainty and the market mechanism. Q J Econ 84: 488-500.

16. Verrecchia RE (2001) Essay on disclosure. J Account Econ 32: 97-180.

17. Vergauwen PGMC, Alem FJC (2005) Annual Report IC Disclosures in the Netherlands, France and Germany. J Intellectual Capital 6: 89-104.

18. Kamath GB (2008) Intellectual Capital and Corporate Performance in Indian Pharmaceutical Industry. J Intellectual Capital 9: 684-704

19. Seleim A, Ashour A, Bontis N (2004) Intellectual Capital in Egyptian Software Firms. Learning Organization 11: 332-346.

20. Bruggen A, Vergauwen P, Dao M (2009) Determinants of intellectual capita disclosure: evidence from Australia. Management Decision 47: 233-245.

21. Kansal M, Singh S (2011) Voluntary Disclosures of Intellectual Capital: An Empirical Analysis. J Intellectual Capital 12: 301-318.

22. Ayee JRA (2008) The Balance Sheet of Decentralization in Ghana. Found Local Gov: 233-258

23. Anaman KA (2006) What Factors Have Influenced Economic Growth in Ghana? Institute of Economic Analysis (IEA), Ghana Policy Analysis 2.

24. Ismail TH (2008) Intellectual Capital Reporting in Knowledge Economy: Evidence from Egypt. International Conference on Economic Directions III: Economic Policy in a Rapidly Changing World, College of Business Administration, Kuwait University, Kuwait.

25. Stewart TA (1997) Intellectual Capital: The New Wealth of Organizations. Doubleday Dell Publishing Group, Inc. New York, USA.

26. An Y, Davey H (2010) Intellectual capital disclosure in Chinese (mainland) companies. J Intellectual Capital 11: 326-347.

27. An Y, Davey H, Eggleton IRC (2011) Towards a comprehensive theoretical framework for voluntary IC Disclosure. J Intellectual Capital 12: 571-585

28. Gowthorpe C (2009) Wider still and wider? A critical discussion of intellectual capital recognition, measurement and control in a boundary theoretical context. Crc Perspect Account 20: 823-834.

29. Nielsen C, Bukh P, Mouritsen J, Johansen MR, Gormsen P (2006) Intellectual capital statements on their way to the stock exchange: Analyzing new reporting systems. J Intellectual Capital 7: 221-240.

30. Vafaei A, Taylor D, Ahmed K (2011) The Value Relevance of Intellectual Capital Disclosures. J Intellectual Capital 12: 407-429.

31. Edvinsson L, Sullivan $P$ (1996) Developing a model for managing intellectual capital. European Management Journal 14: 356-364.

32. Sveiby KE (1997) Intangible Assets Monitor. J Hum Resources Costing \& Account 2: 73-97.

33. Smith A (1976) The theory of moral sentiments. Oxford: Oxford University Press.

34. Riahi-Belkaoui A (2003) Intellectual Capital and Firm Performance of US Multinational Firms: A Study of the Resource-Based and Stakeholder Views. J Intellectual Capital 4: 215-226.

35. Sonnier BM (2008) Intellectual Capital Disclosure: High-Tech Versus Traditional Sector Companies. J Intellectual Capital 9: 705-722.
36. Abeysekera I, Guthrie J (2004) Human capital reporting in a developing nation Br Account Rev 36: 251-268.

37. Cabrita M, Vaz J (2006) Intellectual Capital and Value Creation: Evidence from the Portuguese Banking Industry. Electron J Knowl Manage 4: 11-20

38. Lambert RC, Leuz C, Verrecchia RE (2007) Accounting information, disclosure and the cost of capital. J Account Res 45: 385-420.

39. Chang M, D'Anna G , Watson I, Wee M (2008) Does Disclosure Quality via Investor Relations Affect Information asymmetry? Aust J Manage 33: 375-390.

40. Eustace C (2000) The intangible economy impact and policy issues. Report of the European High Level Expert Group on the Intangible Economy, European Commission. Enterprise Directorate-General, Brussels, Belgium.

41. Abhayawansa S, Abeysekera I (2008) An explanation of human capita disclosure from the resource-based perspective. J Hum Resource Costing \& Account 12: 51-64.

42. Guthrie J, Petty R (2000) Intellectual Capital Literature Review Measurement Reporting and Management. J Intellectual Capital 1: 155-176.

43. Roslender R, Fincham R (2004) Intellectual capital accounting in the UK. Account, Auditing and Accountability J 17: 178-209.

44. Guthrie J, Petty R, Ricceri F (2006) The Voluntary Reporting of Intellectual Capital Comparing Evidence from Hong Kong and Australia. J Intellectual Capital 7: 254-271

45. Abeysekera I (2007) Intellectual capital reporting between a developing and developed nation. J Intellectual Capital 8: 329-345

46. Abeysekera I (2010) The influence of board size on intellectual capital disclosure by Kenyan listed firms. J Intellectual Capital 11: 504-518.

47. Tayib M, Salman RT (2011) Intellectual Capital Reporting in Nigeria: A way forward. $2^{\text {nd }}$ African International Business and Management Conference, in "Building Synergies for Better Performance", in Nairobi, Kenya August 25-26.

48. Haji AA, Gombak J, Mubaraq S (2012) The trends of intellectual capital disclosures: evidence from the Nigerian banking sector. J Hum Resource Costing \& Account 16: 184-209.

49. Guthrie J, Petty R (2000) Intellectual Capital: Australian Annual Reporting Practices. J Intellectual Capital 1: 241-251.

50. April KA, Bosma P, Deglon DA (2003) IC measurement and reporting: establishing a practice in mining. J Intellectual Capital 4: 165-180

51. Guthrie J, Petty R, Yongvanich K, Ricceri F (2004) Using Content Analysis as a Research Method to Inquire into Intellectual Capital Reporting. J Intellectual Capital 5: 282-293.

52. Holland L, Boon Foo Y (2003) Differences in environmental reporting practices in the UK and the US: the legal and regulatory context. Brit Account Rev 35: $1-18$.

53. Gray RH, Kouchy R, Lavers S (1995) Constructing a Research Database of Social and Environmental Reporting by UK Companies: A Methodological Note. J Account, Auditing \& Accountability 8: 78-101.

54. Milne M, Adler R (1999) Exploring the Reliability of Social and Environmental Disclosures Content Analysis. Account, Auditing \& Accountability J 12: 237 256.

55. Williams SM (1999) Voluntary environmental and social accounting disclosure practices in the Asia-Pacific Region: an international empirical test of political economy theory. Int J Account 34: 209-238.

56. Oliveras E, Gowthorpe C, Kasperskaya Y, Perramon J (2008) Reporting Intellectual Capital in Spain.b Corporate Communications: An International Journal 13: 168-181. 